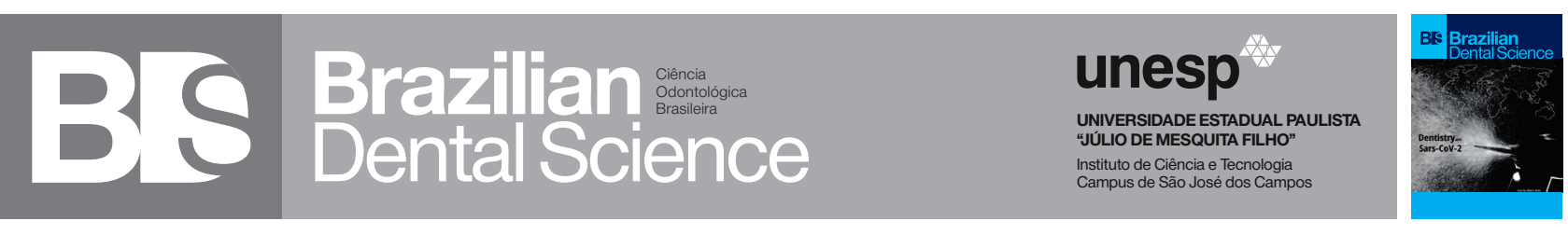

\title{
Assessment of dental care during the COVID-19 pandemic in Turkey and future projections
}

\author{
Avaliação dos cuidados dentários durante a pandemia COVID-19 na Turquia e perspectivas
}

Mehmet Ali KILIÇARSLAN ${ }^{1}$, Figen Çizmeci ŞENEL ${ }^{2}$, Mutlu ÖZCAN ${ }^{3}$

1 - Department of Prosthodontics - Faculty of Dentistry - Ankara University - Ankara - Turkey.

2 - Turkish Healthcare Quality and Accreditation Institute - Ankara - Turkey.

3 - University of Zürich - Division of Dental Biomaterials - Center for Dental and Oral Medicine - Clinic for Reconstructive Dentistry Zürich - Switzerland.

\section{ABSTRACT}

A new coronavirus disease has affected the whole world, starting from Wuhan, China at the end of 2019. The disease, caused by the pathogen of SARS-CoV-2, commonly called COVID-19, has soon passed into the history of epidemics as the most effective pandemic recently. Dentistry has also been significantly affected by the pandemic process, which had a restrictive effect on almost all aspects of social life. Dental treatments are healthcare services that have been applied very carefully in terms of the risk control of cross-infection prior to this pandemic where disinfection and sterilization rules continue to be controlled at the highest level. However, hand instruments used in most dental treatments and generating aerosol has raised concerns, particularly in diseases such as COVID-19, which increase the risk of droplet contamination. This working order is an important risk factor not only for healthcare professionals but also for the contamination of patients and the environment. In addition, the continuing pandemic process and the dynamics of the process require revision of the protocols. For this reason, each country has prepared protocols in order to maintain the dental treatments in the pandemic process in accordance with their own health care conditions and policies. This process caused the dental professionals to reconsider their routine working practices and prospectively, new protocols are recommended for dental applications. This article aims to provide a perspective evaluating the current situation and discuss additional measures to be considered during the pandemic and thereafter.

\section{KEYWORDS}

Coronavirus; SARS-CoV-2; COVID-19 Pandemic; Dentistry, Infection Control; Transmission.

\section{RESUMO}

Uma nova doença por coronavírus afetou o mundo inteiro, a partir de Wuhan, China, no final de 2019. A doença, causada pelo patógeno da SARS-CoV-2, comumente chamada COVID-19, logo passou para a história das epidemias como a pandemia mais eficaz. A odontologia também foi significativamente afetada pelo processo de pandemia, que teve um efeito restritivo em quase todos os aspectos da vida social. Os tratamentos dentários são serviços de saúde que foram sempre aplicados com muito cuidado em termos de controle de risco de infecção cruzada mesmo antes desta pandemia, onde as regras de desinfecção e esterilização continuam a ser controladas ao mais alto nível. No entanto, as turbinas usadas na maioria dos tratamentos odontológicos que geram aerossóis têm suscitado preocupações, principalmente em doenças como a COVID-19, pelo aumento do risco de contaminação por gotículas. Essa mecânica de trabalho é um importante fator de risco não apenas para os profissionais de saúde, mas também para a contaminação dos pacientes e do ambiente. Além disso, o processo continuado da pandemia e sua dinâmica exigem revisão dos protocolos. Por esse motivo, cada país elaborou protocolos para manter os tratamentos dentários no processo de pandemia, de acordo com suas próprias condições e políticas de saúde. Esse processo levou os profissionais de odontologia a reconsiderar suas práticas de trabalho de rotina e, prospectivamente, novos protocolos são recomendados para aplicações odontológicas. Este artigo tem como objetivo fornecer uma perspectiva para avaliar a situação atual e discutir medidas adicionais a serem consideradas durante e após a pandemia.

\section{PALAVRAS-CHAVE}

Coronavírus; SARS-CoV-2; Pandemia do COVID-19; Odontologia, Controle de Infecção; Transmissão. 


\section{BACKGROUND AND CRITICAL REVIEW}

Coronavirus disease, which started in Wuhan, China in December 2019, was first officially announced to the world on January 8, 2020 under the name, COVID-19 [1,2]. The disease, which started as a Pneumonia epidemic due to the pathogen scientifically named as SARS-CoV-2, belonging to the Coronaviridae family, has spread to almost the whole world in a very short time and started a pandemic process that has not been seen for a long time [1-4]. COVID-19 is a zoonotic disease such as Severe Acute Respiratory Syndrome Coronavirus (SARS-CoV) and Middle East Respiratory Syndrome Coronavirus (MERS$\mathrm{CoV}$ ), and is transmitted first from animal to human and then from person to person [5]. This contamination is primarily through respiratory and direct contact mainly due to droplets. One other important risk factor is the fecal-oral passage [6]. In addition, although the most important source of transmission to healthy individuals and the environment is active symptomatic patients, according to recent observations, transmission is possible from asymptomatic individuals or patients in the incubation period $[5,7,8]$. Moreover, it should not be overlooked that this incubation period can be extended up to 14 days [1,9$11]$.

What exactly we know about this virus and its effects is controversial. Most patients experienced the COVID-19 outbreak with relatively mild symptoms. While some patients experience fever, dry cough and myalgia, others presented other atypical symptoms such as shortness of breath, fatigue and muscle pain, confusion, headache, sore throat, diarrhea and vomiting [12-15]. However, most patients undergoing computed tomography (CT) also presented bilateral pneumonia $[13,16]$. Only about a quarter of patients in Wuhan developed serious complications such as acute respiratory distress syndrome, arrhythmia, and shock $[12,16,17]$. Especially until recently, prognosis has been observed to be poor in elderly people and people with systemic diseases. [13,14,16,18]. However, cases of severe or fatal cases are also reported in healthy or young population. On March 11th, 2020 the first cases in Turkey have been seen and the total number of cases during the 3 -months' period. Since then 156.827 cases have been identified with the total number of patients recovering 118.694 . Total number of deaths is 4340 .

Diagnosis of COVID-19; epidemiological information such as travel history, working environment conditions, clinical symptoms such as fever and nausea, CT findings, and laboratory tests such as reverse transcriptase polymerase chain reaction [RT-PCR] on respiratory samples has be performed accurately. [8,17,19]. The Filiation studies carried out in Turkey, has allowed cases of early diagnosis and correct execution of the quarantine process. Even so, the disease is expected to spread to a large part of the world's population in a 3-year period. Undoubtedly, all healthcare workers, especially those who are active in the treatment of COVID-19 carry a great risk for this disease, but it is known that many employees such as teachers, drivers, clerks are at risk both in terms of ventilation of the environment and human contact during the day. Therefore, there is confusion about both precautions and treatment methods and exact mortality rates. Moreover, we witnessed that the decisions made in the pandemic process and the accepted truths changed in a very short time. Since no definitive treatment method and vaccine has been revealed so far, the most definitive precaution remains to control the source of COVID-19 infection. For this purpose, it is important to use infection prevention and control measures to reduce the risk of transmission and to provide early diagnosis, isolation and supportive care for the affected patients $[16,20]$.

After the declaration of the Pandemic, due to regulations of Public Health Emergency of International Concern (PHEIC) by the World Health Organization (WHO) DirectorGeneral extremely important measures were made at a very quick pace in Turkey. In this context, on January 10, 2020, "Coronavirus Scientific Board" has been established within the Turkish Republic Ministry of Health. The scientific committee consists of 34 scientist and includes Infectious Diseases, Public Health, Chest Diseases, Anaesthesiology and 
Reanimation, Emergency Medicine, Virology specialists as well as a dentist. The presence of a dentist in scientific board has enabled actual and accurate implementation of dental practice based on the scientific data in Turkey in the pandemic process.

In a rapidly changing pandemic environment, physicians should actively seek and use reliable sources of information about their patients' treatment methods and the management of the process, in accordance with their region and conditions. From this perspective, revising the hygiene standards in current dentistry practices before pandemic will also be guiding the implementation and determination of the measures to be taken afterwards.

\section{STATUS IN DENTISTRY BEFORE COVID-19 PANDEMIC}

In fact, as in all areas of life, also in dentistry, a dynamic process could be observed in terms of hygiene measures from the past to the future. For instance, almost 30 years ago, wearing gloves were not compulsory in the denal routine, and using a dry air sterilizer was sufficient. However, today such practices are not acceptable. Since all of these developments, including important technological advances in dentistry, have spread to an average of 50 years, none of them were perceived unusual for the patient or the physician. However, the application protocols and the rate of change in the development of the products, which have been brought to the agenda with the COVID-19 pandemic, caused panic and sometimes considered difficult to follow them.

Turkey, as well as in the whole world, even in countries no a pandemic process was experienced, appropriate scientific and legal arrangements were made along with implementation of necessary precautions. Especially during the last 15 years, important arrangements have been made by the Ministry of Health Healthcare Quality System.for dental services in Turkey. Moreover, for healthcare accreditation activities, Turkish HealthCare Quality and Accreditation Institute has been established that provided a very important contribution to the process of managing the pandemic vision. Therefore, the point we were most fortunate in this process in terms of dentistry was that dental profession was already highly educated and conscious about cleaning, disinfection and sterilization.

Dental Health Services in Turkey is currently carried out in private practices, multiunit clinics, oral and dental health centers / hospitals or Faculty of Dentistry Hospitals. These service areas have been standardized with the relevant regulations, for example, the area where a single dental unit will be located has been provided to be not below $12 \mathrm{~m} 2$, except for other dental furniture. Apart from advanced surgical procedures, medical masks and gloves are used during patient care in our routine. In addition, when aerosol generating processes are performed, surgical boné, face shields and goggles were already being used. In recent years, aspirators with high suction power are preferred instead of simple suctions or absorbers during aerosol generating processes. All clinics are cleaned and postpatient unit disinfections are performed at the highest level as if every dental patient has a contagious disease. Dentists and dental assistants also get vaccinated against infectious diseases such as hepatitis B and keep themselves under control for the risk of infection by performing annual routine examinations.

\section{EFFECTS OF COVID-19 ON DENTAL PRACTICE}

Because the most common transmission path is explained as inhalation of airborne droplets, dentistry practices pose a risk area in this regard in two respects. The first of these is mostly long-term and extremely close plans of patients, dentist and other staff in closed examination rooms. In the process of working in the mouth, the interpersonal distance often falls below 1 meter. The second risk area is the use of air-driven handpieces and ultrasonic devices, such as the dental turbines and scalers, which generates aerosols in most dental applications, spreading droplets more than usual. Of course, the contamination caused by contact with the environment 
also causes the clinics to be more threatened than the normal environment due to such level of droplet scattering [21,22]. Because of all this, although dentists have taken the highest level of protection measures known to date, there have been serious concerns about how reliable and sufficient they are for this epidemic period. For this reason, when the literature is studied, many scientific articles about COVID-19 Pandemic and dentistry applications can be found in a short period of up to 3 months. In addition, an approximately 3-month process in Turkey during the pandemic period, only emergency and urgent procedures were carried out in accordance with the recommendations of the Ministry of Health Coronavirus Scientific Committee. These procedures are also applied in a similar way or at least recommended in many other countries [23]. However, postponing not only elective procedures but also non-urgent general treatments and ignoring the treatment needs by patients may lead to an increase in dental ailments or worsening the disease conditions. Thus, it is also possible to expect serious patient accumulation during and after the pandemic process with more advanced level of the disease that could have in fact been solved with simple treatments. Overall, this situation could require implementation of more complicated treatment procedures that would be costly for the patients.

When we try to thoroughly evaluate dentistry services, we need to consider not only the dimension of providing health services but also dental education. In addition to the crowd in preclinical laboratories and classes, the way in which their clinical education has been implemented exceeds the social distance limitation. Although crowded class problems are overcome especially by making theoretical trainings online, preclinical laboratory trainings and clinical trainings that require physical contact are still at risk. As in many countries, patient treatment in Turkey is carried out by students under the supervision of trainers and specialists in multiple unit clinics. For this reason, face-to-face formal education has been interrupted since midMarch, and all trainings and exams have been completed online for the remainder of the 2019-2020 academic year.

\section{RECOMMENDED ADDITIONAL PREVENTIVE PROTOCOLS}

Extraordinary Measures During the COVID-19 Outbreak

At the very beginning of the pandemic process, all dental practice areas, whether private or public, have taken great care to complete their urgent and ongoing work as much as possible. This effort has made a great contribution especially in decreasing the number of patients suffering from urgent dental needs. In the continuation of the process, emergency and urgent dental treatment lists were created in accordance with the measures taken by the Turkish Ministry of Health Science Board based on scientific data and the real situation in our country (Table I). In this context, treatment priority triage was applied to dental patients. These procedures were carried out in isolated clinics using personal protective equipment. It is known that hand hygiene is the most effective method not only in health care but also in the prevention of infection for the whole society. Undoubtedly, high caution was practiced in hand hygiene before and after dental applications [8].

In the vast majority of multi-unit centers, such as faculties, only sufficiently equipped clinics have been kept open in order to prevent contamination throughout the hospital and to prevent the development of nosocomial infections, while other clinics have been closed for this process. The utmost attention has been paid to the ventilation and surface disinfection of open clinics. Dentists and other staff who served in these clinics have worked in designated teams. Flexible working order was initiated, the number of employees was reduced in parallel with the decrease in the number of patients in dental hospitals, and social isolation was ensured at the highest level. 
Table I - Dental Treatment Application Instructions of the Turkish Ministry of Health

\begin{tabular}{|c|c|}
\hline Dental Emergency and Urgent Situe & Dental Service Procedure \\
\hline $\begin{array}{l}\text { 1) Severe toothache caused by pulpal inflammation } \\
\text { 2) Severe pain due to perichoronitis or third molar } \\
\text { 3) Postoperatively developing osteitis or alveolitis } \\
\text { 4) Abscess or bacterial infection causing localized pain and swelling } \\
\text { 5) Tooth fracture causing pain or soft tissue trauma } \\
\text { 6) Traumatic dental avulsion / luxation } \\
\text { 7) Jaw and facial area fractures } \\
\text { 8) Acute and painful lesions / ulcerations of the oral mucosa } \\
\text { 9) Life threatening or uncontrolled bleeding } \\
\text { 10) Intraoral / extraoral infections that threaten the patient's airway } \\
\text { 11) Patients planned or undergoing radiotherapy and chemotherapy and planned } \\
\text { organ transplants } \\
\text { 12) Patients requiring dental consultation for medical problems } \\
\text { 13) Suture removal } \\
\text { 14) Treatment of temporary restoration loss/fractures and treatment of injuries that } \\
\text { hinder the use of removable dentures } \\
\text { 15) Pain and/or infection due to injury in soft tissue as a result of fracture of brackets } \\
\text { and wires of patients undergoing orthodontic treatment } \\
\text { 16) Feeding plate applications of newborn cleft palate patients } \\
\text { 17) TMJ luxation } \\
\text { 18) Biopsy (in cases of suspected malignancy) }\end{array}$ & $\begin{array}{l}\text { 1) It is appropriate to postpone the procedures other than those specified in the den- } \\
\text { tal practices, clinics and centers, where oral and dental health services are provided, } \\
\text { until a second statement is made by the Ministry of Health. } \\
\text { 2) It is appropriate that the specified emergency procedures are performed by defi- } \\
\text { ned fixed teams in at least two shifts and in isolated areas and daily fever monitoring } \\
\text { is made for all teams. } \\
\text { 3) Necessary precautions should be taken for the implementation of social isolation } \\
\text { rules in the patient waiting and treatment areas (ensuring that patients come to their } \\
\text { appointments on time and not waiting in the waiting areas, where patients need to } \\
\text { wait, sitting at a distance of at least 1 meter, removing the magazines, newspapers, } \\
\text { etc. in the waiting areas). } \\
\text { 4) In the treatment rooms, all healthcare personnel who performed an aerosol- gene- } \\
\text { rating procedures should wear N95/FFP2 or equivalent masks, gloves, goggles / face } \\
\text { protective shields, gowns and bonés. } \\
\text { 5) If aerosol-generating procedures are necessary for dental care, use four-handed } \\
\text { dentistry, high evacuation suction and rubber dams to minimize droplet spatter and } \\
\text { aerosols. } \\
\text { 6) As part of routine practice, dental team should be asked to regularly monitor } \\
\text { themselves for fever and symptoms consistent with COVID-19. } \\
\text { 7) Extraoral dental radiographs, such as panoramic radiographs or cone beam CT } \\
\text { and appropriate alternatives should use during the outbreak of COVID-19, as the } \\
\text { intraoral radiographs can stimulate saliva secretion and coughing. }\end{array}$ \\
\hline
\end{tabular}

\section{Recommendations for Future General Treatments}

\section{Suggestions for the Environment}

Firstly, the physical standards of our clinics where we work can change. Clinics where aerosol-generating procedures are performed should be separate from other clinics. Special air sterilizers for these clinics should be evaluated taking the technological developments into account, scientific data and side effects. At least one negative-pressure therapy room can be prepared for patients suffering from COVID-19 infection, or for use in similar infection situations that humanity may encounter thereafter, especially in multiunit centers. Contaminated surfaces should be carefully cleaned with $0.1 \%$ sodium hypochlorite, $70 \%$ ethanol or $0.5 \%$ hydrogen peroxide and wait for 1 minute. [24]. Not only the clinical interior, but also the protection of the environment is extremely important. Liquid wastes may need to be fed into the sewer after special filtering operations. Medical waste protocols should also be universally standardized [22].

\section{Recommendations for Patient Appointments}

Patient care protocols to date should be revised. The patient unit processing times should be shortened and the risk of infection transmission should be minimized by keeping the appointment intervals longer. In the first history of taking an anamnesis, the number of patients who apply to the clinics for information only should be reduced by applying telescreening via telephone or internet, and instead, patients with concrete complaints should be treated first [25]. Tele-screening is also very useful in that it will reduce the length of hospital stay of patients who will be refererd to the hospital under all conditions. In addition, patients who come to the clinic should be evaluated with utmost care in terms of COVID-19 and those with symptoms such as high fever should be monitored [8]. In the evaluation process, extraoral imaging methods should be preferred as much as possible, since intraoral radiographs trigger the cough reflex and increase saliva secretion. It would also be reasonable to classify dental treatments according to their urgency and prioritize patients according to this classification $[23,25]$.

Recommendations for Protection in Chairside Applications

Attention should be paid to hand hygiene and correct determination of protective 
equipment according to the procedure before and after patient treatment. As we cannot currently renounce tools such as a dental turbine, when at least filling, root canal treatment, and dental preparation for the prosthesis, these will require limited and controlled use, even under high protection [25]. Having oral rinse with $0.2 \%$ povidone-iodine or $0.5-1 \%$ hydrogen peroxide prior to treatment, selecting the equipment used as disposable as possible, or using rubber dam in all possible procedures will also reduce the risk of cross infection [8, 21-28].

\section{Education \\ Recommendations for Dentistry}

Turkish dental education in both preclinical and clinical stages is an educational model that covers comprehensive theoretical education supported by practical applications. Depending on the number of students in lecture halls, undoubtedly providing theoretical training on site and applying preclinical laboratory trainings will make conditions difficult after the COVID-19 pandemic. While theoretical training can be provided online, especially clinical practice training needs to be reshaped in the most effective way and the opportunities of technology should be utilized at the highest level [8].

\section{CONCLUSION}

1. COVID-19 pandemic has caused disruptions in most of the routine dental treatment services since March 2020;

2. Although dentistry practices are applied by taking the highest level of hygiene measures in all developed countries, the COVID-19 pandemic process necessitated implementation of additional measures;

3. Both the additional measures and the increase of the equipment used in terms of numbers and qualities have increased the cost of dental service. Therefore, it is necessary to consider the economic burden of all this and its reflection on the service, and develop strategies accordingly;

4. Additional measures and study protocol changes are expected to make significant permanent changes in dental services and practices after the pandemic.

\section{REFERENCES}

1. Li Q, Guan X, Wu P, Wang X, Zhou L, Tong Y, et al. Early transmission dynamics in Wuhan, China, of novel coronavirus-infected pneumonia. N Engl J Med. 2020 Mar;382(13):1199-207. doi: 10.1056/NEJMoa2001316.

2. Zhu N, Zhang D, Wang W, Li X, Yang B, Song J, et al. A novel coronavirus from patients with pneumonia in China, 2019. N Engl J Med. 2020 Feb;382(8):727-33. doi: 10.1056/NEJMoa2001017.

3. Wang C, Horby PW, Hayden FG, Gao GF. A novel coronavirus outbreak of global health concern. Lancet. 2020 Feb;395(10223): 470-3. doi: 10.1016/ S0140-6736(20)30185-9.

4. Gorbalenya AE, Baker SC, Baric RS, de Groot RJ, Drosten C, Gulyaeva AA, et al. The species Severe acute respiratory syndrome-related coronavirus: classifying 2019-nCoV and naming it SARS-CoV-2 Nat Microbiol. 2020 Apr;5(4):536-544. doi: 10.1038/s41564-020-0695-z.

5. Chan JF, Yuan S, Kok KH, To KK, Chu H, Yang J, et al. A familial cluster of pneumonia associated with the 2019 novel coronavirus indicating person-to-person transmission: a study of a family cluster. Lancet. 2020 Feb;395(10223):514-23. doi: 10.1016/S0140-6736(20)30154-9.

6. Holshue ML, DeBolt C, Lindquist S, Lofy KH, Wiesman J, Bruce H, et al. First case of 2019 novel coronavirus in the United States. N Engl J Med. 2020 Mar;382(10):929-36. doi: 10.1056/NEJMoa2001191.

7. Rothe C, Schunk M, Sothmann P,Bretzel G, FroeschI G, Wallrauch C, et al. Transmission of 2019-nCoV infection from an asymptomatic contact in Germany. N Engl J Med. 2020 Mar;382(10):970-1. doi:10.1056/ NEJMc2001468.

8. Meng L, Hua F, Bian Z. Coronavirus disease 2019 (COVID-19): emerging and future challenges for dental and oral medicine. J Dent Res. 2020 May;99(5):481-7. doi: 10.1177/0022034520914246.

9. Backer JA, Klinkenberg D, Wallinga J. Incubation period of 2019 novel coronavirus (2019-nCoV) infections among travellers from Wuhan, China, 20-28 January 2020. Euro Surveill. 2020;25(5):2000062. doi:10.2807/15607917.ES.2020.25.5.2000062.

10. Lai CC, Liu YH, Wang CY, et al. Asymptomatic carrier state, acute respiratory disease, and pneumonia due to severe acute respiratory syndrome coronavirus 2 (SARS-CoV-2): facts and myths. J Microbiol Immunol Infect. 2020;: doi:10.1016/j.jmii.2020.02.012.

11. Lai CC, Shih TP, Ko WC, Tang HJ, Hsueh PR. Severe acute respiratory syndrome coronavirus 2 (SARS-CoV-2) and coronavirus disease-2019 (COVID-19): the epidemic and the challenges. Int J Antimicrob Agents. 2020 Mar;55(3):105924. doi: 10.1016/j.jantimicag.2020.105924.

12. Chen N, Zhou M, Dong X, Qu J, Gong F, Han Y, et al. Epidemiological and clinical characteristics of 99 cases of 2019 novel coronavirus pneumonia in Wuhan, China: a descriptive study. Lancet. 2020 Feb;395(10223):507-13. doi: 10.1016/S0140-6736(20)30211-7.

13. Guan WJ, Ni ZY, Hu Y, Liang WH, Ou CQ, He JX, et al. Clinical characteristics of 2019 novel coronavirus infection in China. N Engl J Med. 2020 Apr;382(18):1708-20. doi: 10.1056/NEJMoa2002032.

14. Giacomelli A, Pezzati L, Conti F, Bernacchia D, Siano M, Oreni L, et al. Selfreported olfactory and taste disorders in SARS-CoV-2 patients: a crosssectional study. Clin Infect Dis. 2020;ciaa330. doi:101093/cid/ciaa330.

15. Wu Z, McGoogan JM. Characteristics of and Important lessons from the coronavirus disease 2019 (covid-19) outbreak in china: summary of a report of 72314 cases from the chinese center for disease control and prevention. JAMA. 2020;10.1001/jama.2020.2648. doi:10.1001/ jama.2020.2648.

16. Wang D, Hu B, Hu C, et al. clinical characteristics of 138 hospitalized patients with 2019 novel coronavirus-Infected pneumonia in Wuhan, China. JAMA. 2020;323(11):1061-9. doi:10.1001/jama.2020.1585. 
17. Huang C, Wang Y, Li X, Ren L, Zhao J, Hu Y, et al. Clinical features of patients infected with 2019 novel coronavirus in Wuhan, China. Lancet. 2020 Feb;395(10223):497-506. doi: 10.1016/S0140-6736(20)30183-5.

18. Kui L, Fang YY, Deng Y, Liu W, Wang MF, Ma JP, et al. Clinical characteristics of novel coronavirus cases in tertiary hospitals in Hubei province. Chin Med J (Engl). 2020 May;133(9):1025-31. doi: 10.1097/ CM1099.0000000000000744.

19. World Health Organization. Clinical management of severe acute respiratory infection (SARI) when novel coronavirus (2019-nCoV) infection is suspected: interim guidance; 13 March 2020 [Internet]. WHO. [cited 2020 May 19]. Available from: https://www.who.int/publications-detail/ clinical-management-of-severe-acute-respiratory-infec tion-when-novelcoronavirus-(ncov)-infection-is-suspected.

20. Casadevall A, Pirofski LA. The convalescent sera option for containing COVID-19. J Clin Invest. 2020;130(4):1545-8. doi:10.1172/JCl138003.

21. Izzetti R, Nisi M, Gabriele M, Graziani F. COVID-19 transmission in dental practice: brief review of preventive measures in Italy. J Dent Res. 2020;22034520920580. doi:10.1177/0022034520920580.

22. Peng X, Xu X, Li Y, Cheng L, Zhou X, Ren B. Transmission routes of 2019-nCoV and controls in dental practice. Int J Oral Sci. 2020;12(1):9. doi:10.1038/s41368-020-0075-9
23. Alharbi A Alharbi S, Alqaidi S Guidelines for dental care provision during the COVID-19 pandemic. Saudi Dent J. 2020;32(4):181-6. doi:10.1016/j. sdentj.2020.04.001.

24. Kampf G, Todt D, Pfaender S, Steinmann E. Persistence of coronaviruses on inanimate surfaces and their inactivation with biocidal agents. J Hosp Infect. 2020;104(3):246-51. doi:10.1016/j.jhin.2020.01.022.

25. Ather A, Patel B, Ruparel NB, Diogenes A, Hargreaves KM. Coronavirus disease 19 (COVID-19): Implications for clinical dental care. J Endod. 2020;46(5):584-95. doi:10.1016/j.joen.2020.03.008.

26. LiZY, Meng LY. Prevention and control of new coronavirus infection in department of stomatology. Chin J Stomatol. 2020;55(0):E001. doi:10.3760/ cma.j.jissn.1002-0098.2020.0001.

27. Eggers M, Koburger-Janssen T, Eickmann M, Zorn J. In vitro bactericidal and virucidal efficacy of povidone-iodine gargle/mouthwash against respiratory and oral tract pathogens. Infect Dis Ther 2018 Jun; 7(2):24959. doi: 10.1007/s40121-018-0200-7.

28. Kariwa H, Fujii N, Takashima I. Inactivation of SARS coronavirus by means of povidone-iodine, physical conditions and chemical reagents. Dermatology. 2006;212 Suppl 1(Suppl 1):119-23. doi:10.1159/000089211.

\section{Prof. Dr. Dr.h.c. Mutlu Özcan}

(Corresponding address)

University of Zürich, Division of Dental Materials, Center for Dental and Oral

Medicine, Clinic for Reconstructive Dentistry, Plattenstrasse 11, CH-8032,

Zürich, Switzerland.

E-mail: mutluozcan@hotmail.com

Date submitted: 2020 May 31

Accept submission: 2020 Jun 01 